\title{
PENGARUH PEMBINAAN TERHADAP KEDISIPLINAN TARUNA DI SEKOLAH TINGGI PERIKANAN JURUSAN PENYULUHAN PERIKANAN BOGOR
}

\author{
THE INFLUENCE OF COACHING ON CADETS DISICIPLINE \\ IN FISHERY HIGH SCHOOL DEPARTMENT OF FISHERY COUNSELING
}

\author{
Adi Apriyadi*, Beddy Iriawan Maksudi ${ }^{2}$, Denny Hernawan ${ }^{3}$ \\ 1Jurusan Ilmu Administrasi Negara Fakultas Ilmu Sosial dan Ilmu Politik Universitas \\ Djuanda, Jl. Tol Ciawi No.1, Kotak Pos 35 Bogor 16770 \\ 2Jurusan Ilmu Administrasi Negara Fakultas Ilmu Sosial dan Ilmu Politik Universitas \\ Djuanda, Jl. Tol Ciawi No.1, Kotak Pos 35 Bogor 16770 \\ 3Jurusan Ilmu Administrasi Negara Fakultas Ilmu Sosial dan Ilmu Politik Universitas \\ Djuanda, Jl. Tol Ciawi No.1, Kotak Pos 35 Bogor 16770 \\ *Korespondensi: Adi Apriyadi, Email : adi.apriyadi@unida.ac.id
}

(Diterima oleh Dewan Redaksi: 01-08-2017)

(Dipublikasikan oleh Dewan Redaksi: 01-10-2017)

\begin{abstract}
The purpose of this research are : (1) to know how the coaching of cadets in STP Bogor Fishery Counseling Department, (2) to know how the influence of coaching on cadet discipline in Fishery High School Bogor, Department of Fisheries Counseling, and (3) to know what factors are influence the coaching process in improving cadet discipline. The research method used by researcher is descriptive research method. The sampling technique using in this research is the formula of Taro Yamane and Slovin with the number of pupolation as many as 76 people cadets.

Result of analysis of correlation coefficient test showed that with sample number of 76 people and trust level of 0.05 or $95 \%$ coaching variable (X) and discipline variable (Y) have correlation value of 0,742 and significance level equal to $0.001<a \quad 0.05$ or $95 \%$ of confidence level. This mean that the value asserts that the coaching variables have a strong and significant relationship, so the hypothesis proposed was accepted. From many indicators that can affect the level of cadet discipline in the Fishery High School of Bogor, Department of Fisheries Counseling one of them is coaching factor. Coaching is instrumental in determining the cadets' divinity, because the Coach is used as an example and role model by the cadets. The coach should not expect the discipline as good as it is if his coaches can not exemplify discipline.

Good discipline reflects the magnitude of a person's sense of responsibility for the tasks assigned to him. This encourages the passion of learning and follow all activities that available and can realize the goal of the Fishery High School of Bogor, Department of Fisheries Counseling. The amount of determination coefficient between the variables of coaching on cadet discipline in Fishery High School Department of Fisheries Counseling is equal to $51.1 \%$, while the rest is equal to $48.9 \%$
\end{abstract}

Keywords: Coaching, Cadet Discipline 
Tujuan penelitian ini adalah mengetahui bagaimana pelaksanaan pembinaan taruna di STP Jurusan Penyuluhan Perikanan Bogor, mengetahui Bagaimana pengaruh pembinaan terhadap kedisiplinan taruna di Sekolah Tinggi Perikanan Jurusan Penyuluhan Perikanan Bogor, dan Mengetahui Faktor-faktor apa saja yang mempengaruhi proses pembinaan dalam meningkatkan kedisiplinan taruna.

Metode penelitian yang digunakan oleh peneliti adalah metode Penelitian Deskriptif. Dalam hal ini penelitian Teknik pengambilan sampel menggunakan rumus dari Taro Yamane dan Slovin dengan jumlah pupolasi sebanyak 76 orang taruna.

Hasil analisis uji koofisien korelasi menunjukkan bahwa dengan jumlah sampel 76 orang dan taraf kepercayaan sebesar 0.05 atau 95\% variabel pembinaan (X) dan Variabel Kedisiplinan (Y) memiliki nilai korelasi 0,742 dan taraf signifikansi sebesar $0.001<$ a 0.05 taraf kepercayaan 95\%. Artinya dengan nilai tersebut menegaskan bahwa varibel pembinaan memiliki hubungan yang kuat dan signifikan, dengan demikian hipotesis yang diajukan ternyata diterima. Dari sekian banyak indikator yang dapat mempengaruhi tingkat kedisiplinan taruna di Sekolah Tinggi Perikanan Jurusan Penyuluhan Perikanan Bogor diantaranya adalah faktor pembinaan. Pembinaan sangat berperan dalam menetukan kedisiplina taruna, karena pembina dijadikan contoh dan panutan oleh para taruna. Pembina jangan mengharapkan kedisiplinan tarunanya baik jika pembinanya sendiri tidak dapat mencontohkan kedisiplinan.

Disiplin yang baik mencerminkan besarnya rasa tanggung jawab seseorang terhadap tugas-tugasnya yang diberikan kepadanya. Hal ini mendorong gairah belajar dan mengiktui seluruh kegiatan yang ada serta dapat mewujudkan tujuan dari Sekolah Tinggi Perikanan Jurusan Penyuluhan Perikanan Bogor. Besarnya koofisien determinasi antar variabel pembinaan terhadap kedisiplinan taruna di Sekolah Tinggi Perikanan Jurusan Penyuluhan Perikanan ini adalah sebesar 51.1\%, sedangkan sisanya sebesar $48.9 \%$

Kata kunci: Pembinaan, Disiplin Taruna

Adi Apriyadi, 2017. Pengaruh Pembinaan Terhadap Terhadap Kedisiplinan Taruna Di

Sekolah Tinggi Perikanan Jurusan Penyuluhan Perikanan Bogor. Jurnal Governansi 


\section{PENDAHULUAN}

Kedisiplinan adalah kondisi yang telah diciptakan dan terbentuk melalui suatu proses dari serangkaian perilaku yang menunjukkan nilai-nilai kepatuhan, ketaatan, kesetiaan, keteraturan dan ketertiban. Oleh karena sudah menyatu nilai-nilai tersebut, maka perbuatan yang dilakukan bukan lagi dirasakan sebagai sebuah beban, malah sebaliknya akan membebani dirinya sendiri jika dia tidak bertindak sebagaimana biasanya. Kedisiplinan pada dasarnya merupakan sekumpulan perilaku perorangan maupun sekelompok orang yang mendeskripsikan rasa kepatuhan, ketaatan, secara sadar mendukuang untuk melaksanakan tugas dan fungsi dalam mencapai tujuan tertentu.

Pembinaan adalah suatu proses yang berkesinambungan dan tidak ada rencana pembinaan bersifat final. Berdasarkan hal tersebut pembinaan bisa ditinjau dari dua perspektif, yaitu pertama berasal dari perspektif pembaharuan dan yang kedua berasal dari perspektif controling (pengawasan). Pembinaan yang bersumber dari perspektif pembaharuan bermakna mengubah suatu hal menjadi yang baru dan mempunyai nilai-nilai lebih baik untuk kehidupan masa depan. Sedangkan pembinaan yang berasal dari perspektif controling (pengawasan) bermakna usaha untuk membuat sesuatu lebih relevan dengan kebutuhan yang direncanakan baik secara langsung maupun secara tidak langsung. Dalam proses pembinaan banyak faktor penentu keberhasilan agar proses pembinaan dapat tersebut dapat bermanfaat bagi individu maupun sekelompok individu antara lain : 1) Tujuan pembinaan, 2) Lamanya waktu proses pembinaan, dan 3) Metode pembinaan yang diterapkan.
Proses pembinaan dalam meningkatkan kedisiplinan taruna tidak lepas dari peranan pembina ketarunan. Di sekolah tinggi perikanan Jurusan Penyuluhan Perikanan jumlah pembina taruna yang ada saat ini tidak sebanding dengan jumlah taruna yang ada sehingga proses pembinaan tidak optimal. Jumlah pembina taruna yang ada saat ini hanya 4 (empat) orang dengan jumlah taruna 314 orang.

Adapun tujuan penelitian ini adalah: 1). Mengetahui Bagaimana pelaksanaan pembinaan taruna di STP Jurusan Penyuluhan Perikanan Bogor. 2). Mengetahui Bagaimana pengaruh pembinaan terhadap kedisiplinan taruna di Sekolah Tinggi Perikanan Jurusan Penyuluhan Perikanan Bogor., 3). Mengetahui Faktor-faktor apa saja yang mempengaruhi proses pembinaan dalam meningkatkan kedisiplinan taruna.

Berdasarkan fenomena di atas maka penulis tertarik untuk mengadakan penelitian dengan judul. "Pengaruh Pembinaan Terhadap Kedisiplinan Taruna di STP Jurusan Penyuluhan Perikanan Bogor".

\section{TINJAUAN PUSTAKA}

Disiplin adalah sikap yang menggambarkan kepatuhan pada suatu peraturan (aturan) atau ketentuan yang berlaku dan merupakan suatu tuntutan bagi berlangsungnya kehidupan bersama yang teratur, tertib yang merupakan syarat mutlak bagi berlangsungnya suatu kemajuan dan perkembangan". (Supriyadi, 2000).

Menurut Nanang Fattah 2009, Dalam proses pembinaan ada beberapa indikator yang mempengaruhi pembinaan tersebut, yaitu aspek 
perencanaan, pengorganisasian dan Pengendalian (monitoring dan evaluasi).

Aspek perencanaan merupakan proses menentukan tujuan atau sasaran yang akan dicapai serta menetapkan jalan dan sumber yang dibutuhkan untuk mencapai tujuan tersebut seefisian dan seefektif mungkin. Dalam setiap perencanaan mencakup perumusan tujuan yang ingin dicapai, pemilihan program untuk mencapai tujuan.

$$
\text { Kedisiplinan adalah kunci }
$$

terwujudnya tujuan sebuah organisasai, karena jika kedisiplinan terwujud dengan baik maka akan muncul kesadaran dalam diri pegawai dan menjalankan tugas serta fungsinya dengan baik. Menurut Malayu SP. Hasibuan 2002, dalam bukunya yang berjudul Manajemen Sumber Daya Manusia menyebutkan indikator-indikator yang mempengaruhi terhadap disiplin, yaitu :1. Tujuan 2. Pengawasan melekat, 3. Sanksi (hukuman).

Metode penelitian memberikan petunjuk kepada peneliti mengenai urutan-urutan bagaimana penelitian akan dilaksanakan. Maka penelitian ini, menggunakan metode Kuantitatif. Arikunto menjelaskam "penelitian Kuantitatif adalah penelitian yang bertujuan untuk menggali secara luas tentang sebab-sebab atau hal-hal yang mempengaruhi terjadinya Sesuatu."

\section{METODOLOGI PENELITIAN}

Metode penelitian memberikan petunjuk kepada peneliti mengenai urutan-urutan bagaimana penelitian akan dilakukan. Penelitian ini, menggunakan metode eksploratif. Arikunto menjelaskam "penelitian eskploratif merupankan penelitian yang bertujuan untuk menggali secara luas tentang sebabsebab atau hal-hal yang mempengaruhi terjadinya sesuatu".

Populasi ialah segala nilai hasil pengukuran maupun perhitungan, baik secara kuantitatif maupun secara kualitatif, dari karakteristik tertentu tentang sekelompok obyek yang jelas dan lengkap. Menurut Sugiono, Populasi adalah wilayah generalisasi yang terdiri atas obyek atau subyek yang mempunyai kualitas dan karakteristik tertentu yang ditetapkan oleh peneliti untuk dipelajari dan kemudian ditarik kesimpulannya. Dengan demikian populasi bukan hanya jumlah yang ada pada subyek atau obyek yang dipelajari, akan tetapi meliputi semua karakteristik yang dimiliki. Sedangkan menurut Arikunto, Populasi adalah keseluruhan subyek penelitian. Dalam hal ini penelitian mengambil subyek seluruh Taruna Tingkat I-IV di Sekolah Tinggi Perikanan Jurusan Penyuluhan Perikanan Bogor 314 siswa sebagai populasi

Sampling adalah suatu teknik yang dilakukan oleh peneliti didalam mengambil atau menentukan sampel penelitian. Untuk memutuskan sampel yang akan dipakai dalam peneltian bisa menggunakan berbagai teknik. Adapun teknik sampling yang dipakai dalam penelitian ini adalah Simple Random Sampling.

Dikatakan simple (sederhana) sebab sampel yang diambil dari anggota populasi dilakukan secara random (acak) tanpa melihat strata yang ada di dalam populasi itu. Dengan demikian dapat diketahui bahwa teknik Simple Random Sampling merupakan teknik pengambilan sampel yang digunakan apabila populasi memiliki anggota yang dianggap homogen sehingga diperoleh anggota sampel yang representif.

Data adalah kumpulan hasil pengukuran yang diperoleh dari pengamatan. Data kata asalnya dari bahasa Inggris "data" yang merupakan jamak "datum" dalam kamus InggrisIndonesia oleh John M. Echols dan Hasan Shadili merupakan fakta atau keterangan-keterangan. Jadi data 
adalah catatan fakta-fakta atau keterangan-keterangan yang akan diolah dalam kegiatan penelitian.

Jenis data dalam penelitian ini yaitu pertama data primer dan kedua data sekunder. Data primer merupakan data yang dapat dikumpulkan atau diperoleh langsung oleh peneliti atau sumbernya dengan menggunakan metode pengumpulan data yang sesuai. Data primer berisi jawaban dari kuesioner atau angket yang diberikan kepada subyek penelitian. Data primer dari penelitian ini berupa angket, sedangkan data sekunder adalah data yang secara tidak langsung dikumpulkan oleh orang yang berkepentingan dengan data tersebut. Data sekunder dalam penelitian ini adalah data tentang jumlah Taruna yang diperoleh dari Badan administrasi, akademik dan Ketarunaan.

Sumber data yang dimaksud dalam penelitian adalah subyek dari mana data bisa didapatkan. Jika peneliti memakai angket atau wawancara dalam mengumpulkan datanya, maka data itu disebut responden. Responden adalah individu yang menjawab pertanyaan-pertanyaan dari peneliti, baik pertanyaan secara tertulis maupun secra lisan.

Sumber data yang dipakai di dalam peneltian ini adalah : Taruna Sekolah Tinggi Perikanan Jurusan Penyuluhan Perikanan Bogor, data hasil angket.

Alasan dipilihnya jenis penelitian ini karena ingin mengetahui berapa besaran pengaruh Pembinaan terhadap Kedisiplinan Taruna. Penelitian ini memiliki dua variabel yakni variabel bebas (X) Pengaruh Pembinaan dan variabel terikat (Y) yaitu Kedisiplinan Taruna di Sekolah Tinggi Perikanan Jurusan Penyuluhan Perikanan Bogor.

Menurut Ibnu Hadjar bahwa : pada hakikatnya pengukuran terhadap variabel merupakan proses pemberian simbol-simbol berupa angka kuantitatif tersebut dimaksudkan untuk memberikan informasi tentang karakteristik yang melekat pada obyek pengamatan yang dimiliki oleh suatu unit. Berdasarkan pendapat diatas, maka variabel bebas (peningkatan disiplin) diukur melalui angket berskala likert, yakni pengukuran yang "didasarkan pada ranking diurutkan dari jenjang lebih tinggi sampai jenjang terendah atau sebaliknya". Bahwa semakin tinggi skor diperoleh, maka akan terjadi semakin baik hasilnya, yang diisi oleh subyek penelitian dan variabel terikat (peningkatan disiplin belajar) juga diukur melalui angket berskala likert dengan kriteria tinggi kemudian sedang dan rendah.

Pengumpulan data merupakan suatu prosedur yang standar dan sistematik untuk mendapatkan data yang akan dibutuhkan. Untuk memperoleh data yang akan dibutuhkan dalam penelitian ini, peneliti menggunakan beberapa tehnik metode lapangan dengan Metode Angket, Metode Observasi (Observation), Metode Dokumentasi, dan Wawancara.

Dalam penelitian ini menggunakan teknik penganalisaan data kuantitatif. Hal ini berdasarkan pendekatan yang dipakai dalam penelitian ini yakni pendekatan kuantitatif. Tujuan dilakukannya analisis data yaitu mendeskripsikan data dan membuat induksi atau membuat kesimpulan mengenai karakteristik populasi yang didsarkan atas perolehan dari sampel penelitian.

Lokasi penelitian tentang Pengaruh Pembinaan Terhadap Peningkatan Kedisiplinan Taruna di Sekolah Tinggi Perikanan Jurusan Penyuluhan Perikanan Bogor. 


\section{HASIL DAN PEMBAHASAN}

Sebagaimana Peraturan Menteri Kelautan dan Perikanan nomor PER.19/MEN/2006 tentang Organisasi dan Tata Kerja Sekolah Tinggi Perikanan sebagaimana telah diubah dengan Peraturan Menteri Kelautan dan Perikanan nomor PER.42/MEN/2011, Sekolah Tinggi Perikanan adalah Perguruan Tinggi Kedinasan di lingkungan Kementerian Kelautan dan Perikanan yang berada di bawah dan bertanggung jawab kepada Menteri Kelautan dan Perikanan melalui Kepala Badan Pengembangan Sumber Daya Manusia dan Pemberdayaan Masyarakat Kelautan dan Perikanan. Pembinaan secara teknis akademik dilakukan oleh Menteri Pendidikan Nasional melalui Direktur Jenderal Pendidikan Tinggi, dan pembinaan teknis fungsional dilakukan Menteri Kelautan dan Perikanan melalui Kepala Badan Pengembangan Sumber Daya Manusia dan Pemberdayaan Masyarakat Kelautan dan Perikanan. Sekolah Tinggi Perikanan (STP) mempunyai tugas menyelenggarakan program pendidikan profesional keahlian di bidang perikanan.

Adapun alat yang digunakan dalam penghitungan analisis deskriptif pada penelitian ini yaitu penulis menggunakan aplikasi SPSS V17, Adapun hasil penelitian yang diperoleh dari lapangan disajikan sebagai berikut.

\section{Tabel Hasil Statistic Deskriptif Descriptive Statistics}

\begin{tabular}{|l|c|c|c|}
\hline & $\mathrm{N}$ & Mean & \multicolumn{1}{c|}{$\begin{array}{c}\text { Std. } \\
\text { Deviation }\end{array}$} \\
\hline PEMBINAAN & 76 & 39.7368 & 3.92044 \\
DISIPLIN & 76 & 34.7237 & 3.23975 \\
Valid N & 76 & & \\
(listwise) & & & \\
\hline
\end{tabular}

Sumber : Hasil Penelitian Tahun 2017
Dari tabel descriptive statistics di atas menunjukkan bahwa rata-rata Pembinaan (X) sebesar 39,7368 dengan standar deviasi sebesar 3,92044 dengan jumlah responden sebanyak 76, sedangkan Kedisiplinan (Y) sebesar 34,7237 dengan standar deviasi sebesar 3,23975 . Dengan demikian data yang diambil dari sampel dinilai representatif karena nilai mean lebih besar dari standard deviasi.

Adapun rekapitulasi dari jawaban responden atas variabel pembinaan di Sekolah Tinggi Perikanan Jurusan Penyuluhan Perikanan Bogor dapat dilihat pada tabel dibawah ini

Tabel Hasil Rekapitulasi Jawaban Variabel Pembinaan (X)

\begin{tabular}{|c|l|c|c|}
\hline No. & Indikator & $\begin{array}{c}\text { Hasil } \\
\text { Penilaian }\end{array}$ & $\begin{array}{c}\text { Hasil } \\
\text { Penafsiran }\end{array}$ \\
\hline 1 & $\begin{array}{l}\text { Perumusan } \\
\text { Tujuan }\end{array}$ & 4.43 & $\begin{array}{c}\text { Sangat } \\
\text { baik }\end{array}$ \\
\hline 2 & $\begin{array}{l}\text { Jumlah } \\
\text { Pembina }\end{array}$ & 4.43 & $\begin{array}{c}\text { Sangat } \\
\text { baik }\end{array}$ \\
\hline 3 & $\begin{array}{l}\text { Media Yang } \\
\text { Digunakan }\end{array}$ & 4.43 & $\begin{array}{c}\text { Sangat } \\
\text { baik }\end{array}$ \\
\hline 4 & Monitoring & 4.66 & $\begin{array}{c}\text { Sangat } \\
\text { baik }\end{array}$ \\
\hline 5 & Evaluasi & 4.39 & $\begin{array}{c}\text { Sangat } \\
\text { baik }\end{array}$ \\
\hline & JUMLAH & $\mathbf{4 . 4 6}$ & $\begin{array}{c}\text { Sangat } \\
\text { baik }\end{array}$ \\
\hline
\end{tabular}

Sumber : Hasil Penelitian 2017

Berdasarkan hasil dari perhitungan rekapitulasi mengenai variabel Pembinaan menunjukkan nilai 4,46. Dengan demikian Pembinaan di Sekolah TinggI perikanan Jurusan Penyuluhan Perikanan Bogor digolongkan Sangat Baik. Namun salah satu indikator Pembinaa harus ditingkatkan, khususnya pada Evaluasi pembinaan, yang nilainya 4,39 .

Adapun rekapitulasi dari jawaban responden atas variabel kedisiplinan di Sekolah Tinggi Perikanan Jurusan 
Penyuluhan Perikanan Bogor dapat dilihat pada tabel dibawah ini

\section{Tabel Hasil Rekapitulasi Variabel Kedisiplinan (Y)}

\begin{tabular}{|c|l|c|c|}
\hline $\begin{array}{c}\text { No } \\
\cdot\end{array}$ & Indikator & $\begin{array}{c}\text { Hasil } \\
\text { Penilaia } \\
\mathrm{n}\end{array}$ & $\begin{array}{c}\text { Hasil } \\
\text { Penafsira } \\
\mathrm{n}\end{array}$ \\
\hline 1 & $\begin{array}{l}\text { Sasaran } \\
\text { Yang Ingin } \\
\text { Dicapai }\end{array}$ & 4.39 & $\begin{array}{c}\text { Sangat } \\
\text { baik }\end{array}$ \\
\hline 2 & Monitoring & 4.49 & $\begin{array}{c}\text { Sangat } \\
\text { baik }\end{array}$ \\
\hline 3 & Evaluasi & 4.37 & $\begin{array}{c}\text { Sangat } \\
\text { baik }\end{array}$ \\
\hline 4 & Motivasi & 4.36 & $\begin{array}{c}\text { Sangat } \\
\text { baik }\end{array}$ \\
\hline 5 & Sangsi Fisik & 3.96 & $\begin{array}{c}\text { Sangat } \\
\text { baik }\end{array}$ \\
\hline 6 & $\begin{array}{l}\text { Sangsi } \\
\text { Administras } \\
\text { i }\end{array}$ & 4.41 & $\begin{array}{c}\text { Sangat } \\
\text { baik }\end{array}$ \\
\hline & JUMLAH & $\mathbf{4 . 3 3}$ & $\begin{array}{c}\text { Sangat } \\
\text { baik }\end{array}$ \\
\hline
\end{tabular}

Sumber : Hasil Penelitian 2017

Berdasarkan hasil dari perhitungan rekapitulasi variabel kedisiplinan di Sekolah Tinggi Perikanan Jurusan Penyuluhan Perikanan Bogor menunjukkan nilai 4.33. dengan demikian kedisiplinan taruna di Sekolah Tinggi Perikanan Jurusan Penyuluhan Perikanan digolongkan sangat baik. Namun salah satu indikator sangsi fisik harus di evaluasi yang nilainya kurang dari 4.00. dengan demikian sangsi fisik harus dievaluasi guna perbaikan kedisiplinan taruna kedepannya.

Berdasarkana hasil dari perhitungan rekapitulasi variabel pembinaan di Sekolah Tinggi Perikanan Jurusan Penyuluhan Perikanan Bogor baik dari indikator perumusan tujuan, jumlah pembina, media yang digunakan, monitoring, evaluasi menunjukkan nilai 4.46 yang di dapat dari tanggapan responden terhadap pertanyaan yang diajukan. Dengan demikian Pembinaan taruna di Sekolah Tinggi Perikanan Jurusan Penyuluhan Perikanan di golongkan sangat baik.

Disiplin merupakan suatu hal yang sangat penting bagi seorang taruna dalam melangsungkan kegiatan selama perkuliahannya di Sekolah Tinggi Perikanan Jurusan Penyuluhan Perikanan Bogor. Hal ini disebabkan hanya dengan disiplin yang tinggi seorang taruna dapat berprestasi tinggi. Maka dari itu, disiplin berarti unsur yang paling penting yang mempengaruhi prestasi serorang taruna. Tidak ada taruna yang berprestasi lebih baik tanpa melaksanakan disiplin dalam derajat yang lebih baik lagi.

Berdasarkan hasil dari perhitungan rekapitulasi variabel kedisiplinan di Sekolah Tinggi Perikanan Jurusan Penyuluhan Perikanan Bogor baik dari indikator perumusan tujuan, jumlah pembina, media yang digunakan, monitoring, evaluasi menunjukkan nilai 4.33 yang di dapat dari tanggapan responden terhadap pertanyaan yang diajukan. Dengan demikian kedisiplinan taruna di Sekolah Tinggi Perikanan Jurusan Penyuluhan Perikanan di golongkan sangat baik.

Berdasarkan pengujian hipotesis yang menyatakan ada pengaruh pembinaan dalam kedisiplinan taruna di Sekolah Tinggi Perikanan Jurusan Penyuluhan Perikanan Bogor dapat dilihat dari hasil analisis uji signifikansi koofisien korelasi. Hasil analisis uji koofisien korelasi menunjukkan bahwa dengan jumlah sampel 76 dan taraf kepercayaan sebesar 0.05 atau $95 \%$ variabel pembinaan $(\mathrm{X})$ dan Variabel Kedisiplinan (Y) memiliki nilai korelasi 0,742 dan taraf signifikansi sebesar $0.001<$ a 0.05 taraf kepercayaan. Artinya dengan nilai tersebut menegaskan bahwa 
varibel pembinaan memiliki hubungan yang kuat dan signifikan jika dilihat dari tabel interpretasi yang dikemukakan oleh Sugiyono.

Hal di atas menegaskan benar apa yang dikatakan oleh hasibuan (2002), bahwa dari sekian banyak indikator yang dapat mempengaruhi tingkat kedisiplinan taruna di Sekolah Tinggi Perikanan Jurusan Penyuluhan Perikanan Bogor diantaranya adalah faktor pembinaan. pembinaan sangat berperan dalam menetukan kedisiplina taruna, karena pembina dijadikan contoh dan panutan oleh para taruna. Pembina jangan mengharapkan kedisiplinan tarunanya baik jika pembinanya sendiri tidak dapat mencontohkan kedisiplinan.

Penelitian ini diharapkan memberikan tambahan pengetahuan yang berkaitan dengan pengaruh pembinaan terhadap kedisiplinan taruna. Penelitian ini juga dapat memberikan perspektif mengenai pentingnya pembinaan khususnya sebagai upaya untuk menjaga tingkat kedisiplinan taruna secara maksimal. Oleh sebab itu, ketika dikaitkan dengan teori, bahwa penelitian ini menunjukkan memang benar jika pembinaan menjadi salah satu faktor yang mempengaruhi dan menentukan disiplin taruna.

Penelitian ini memiliki implikasi langsung bagi pihak akademik Sekolah Tinggi Perikanan Jurusan Penyuluhan Perikanan Bogor. Dimana pembinaan dan kedisiplinan yang baik sangat dibutuhkan dalam mencapai tujuan proses belajar mengajar maupun dalam pelaksanaan kegiatan selama menjadi taruna di Sekolah Tinggi Perikanan Jurusan Penyuluhan Perikanan Bogor.

\section{PENUTUP}

Dari analisa yang telah dilakukan dapat dilihat/diperoleh bahwa rata-rata (R) angka penafsiran variabel pembinaan (Rx) adalah 4.46, ternyata hubungan kepemimpinan termasuk kategori sangat baik, dan rata-rata angka penafsiran kedi-siplinan taruna (Ry) adalah 4.33. Setelah dilihat ternyata tingkat kedisiplinan taruna sangat baik. Ini berarti terdapat hubungan antara variabel dalam penelitian tersebut.

Laporan skripsi ini juga menunjukan bahwa pembinaa merupakan salah satu faktor peningkatan disiplinan taruna. Berdasarkan pengujian hipotesis yang menyatakan ada pengaruh pembinaan dalam kedisiplinan taruna di Sekolah Tinggi Perikanan Jurusan Penyuluhan Perikanan Bogor dapat dilihat dari hasil analisis uji signifikansi koofisien korelasi. Hasil analisis uji koofisien korelasi menunjukkan bahwa dengan jumlah sampel 76 orang dan taraf kepercayaan sebesar 0.05 atau $95 \%$ variabel pembinaan (X) dan Variabel Kedisiplinan (Y) memiliki nilai korelasi 0,742 dan taraf signifikansi sebesar $0.001<$ a 0.05 taraf kepercayaan 95\%. Artinya dengan nilai tersebut menegaskan bahwa varibel pembinaan memiliki hubungan yang kuat dan signifikan, dengan demikian hipotesis yang diajukan ternyata diterima.

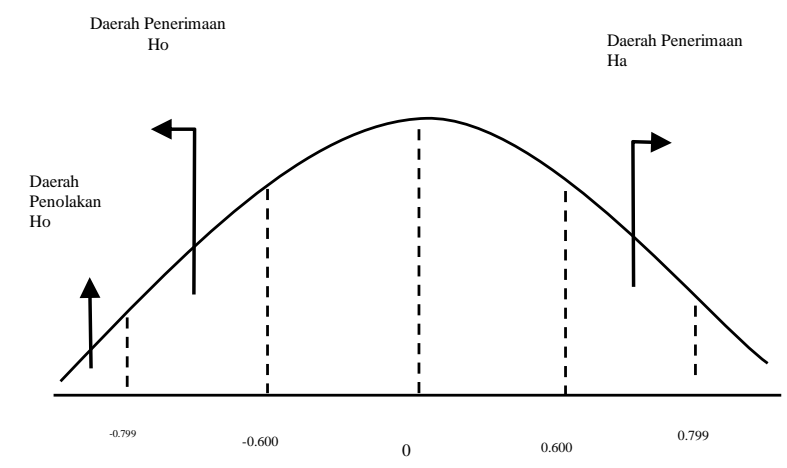

Gambar 1. Grafik Hipotesis 
Dari sekian banyak indikator yang
dapat mempengaruhi tingkat kedisiplinan taruna di Sekolah Tinggi Perikanan Jurusan Penyuluhan Perikanan Bogor diantaranya adalah faktor pembinaan. pembinaan sangat berperan dalam menetukan kedisiplina taruna, karena pembina dijadikan contoh dan panutan oleh para taruna. Pembina jangan mengharapkan kedisiplinan tarunanya baik jika pembinanya sendiri tidak dapat mencontohkan kedisiplinan.

Selain itu, besarnya koofisien determinasi antar variabel pembinaan terhadap kedisiplinan taruna di Sekolah Tinggi Perikanan Jurusan Penyuluhan Perikanan ini adalah sebesar 51.1\%, sedangkan sisanya sebesar $48.9 \%$ dipengaruhi oleh variabel lain yang tidak dimasukkan dalam model yang diajukan dalam penelitian ini. Jadi semakin tinggi proses pembinaan, maka semakin tinggi pula kedisiplinan yang dimiliki oleh taruna di Sekolah Tinggi Perikanan Jurusan Penyuluhan Perikanan Bogor, demikian pula sebaliknya.

Berdasarkan kesimpulan yang diperoleh dalam penelitian ini, maka diajukan saran-saran sebagai pelengkap pembinaan terhadap kedisiplinan taruna di Sekolah Tinggi Perikanan Jurusan Penyuluhan Perikanan Bogor. sebagai berikut :1). Pembinaan kedisiplinan yang sudah dilaksanakan selama ini di Sekolah Tinggi Perikanan Jurusan Penyuluhan Perikanan Bogor sudah sangat baik, dengan sistem pembinaan yang berjenjang dimulai dari senior kepada juniornya serta pembinaan yang langsung diawasi oleh pembina ketarunaan dapat mengontrol dan mengawasi setiap kegiatan yang berlangsung selama taruna tersebut berada di dalam atau dluar kampus. 2). Pengaruh pembinaan terhadap kedisiplinan taruna sangatlah besar, seorang pembina menjadi contoh atau panutan terhadap taruna didiknya. Dengan pembina turun langsung mengawasi serta mengotrol setiap kegiatan dimulai dari kegiatan pagi sampai dengan kegiatan malamnya menjadikan taruna termotivasi untuk disiplin. Sehingga kedepannya untuk pembina merupakan contoh baik dalam berdisiplin sehingga dapat memotivasi taruna melaksanakan setiap kegiatan dengan baik. 3). Dalam proses pembinaan banyak hal yang mesti diperhatikan, antara lain perlu ditingkatkan lagi pengawasn yang dilakukan oleh pembina kepada taruna dalam setiap kegiatan agar setiap kegiatan berjalan dengan baik, sangsi baik secara fisik dan administrasi harus ditenggakkan secara objektif terhadap tingkat kesalahan yang diperbuat sehingga dengan demikian dapat menjadi batasan bagi taruna agar tidak melakukan kesalahan atau pelanggaran selama mengikuti perkuliahan di Sekolah Tinggi Perikanan Jurusan Penyuluhan.

\section{DAFTAR PUSTAKA}

Alwi, Hasan. 2007. Kamus Besar Bahasa Indonesia. Jakarta: Balai Pustaka.

Arikunto, S. 2002. Prosedur penelitian. Jakarta: PT . Rineka Cipta.

John M. Echols dan Hasan Shadili Januari 1988 Kamus : Inggris Indonesia Gramedia Pustakan Utama.

M. Natsir 2003. Metode Penelitian Bandung : Universitas Padjadjaran Bandung.

Nanang Fattah. 2009. Landasan manajemen pendidikan. Bandung : Remaja Rosdakarya.

Sugiyono. 2012. Metode Penelitian Kuantitatif Kualitatif dan R\&D. Bandung: Alfabeta.

Supriyadi, Gering. 2000. Etika Birokrasi. Jakarta : LAN. 
Thoha, Mifta. 1997. Pembinaan Organisasi. Jakarta : Raja Grafindo Persada.

Tulus, Tu'u. 2004. Peran Disiplin pada Perilaku dan Prestasi Belajar. Jakarta: Grasindo.

Westa. 1985. Psikologi Pengajaran. Jakarta: Media Abadi.

Wrihatnolo Randy R. \& Riant Nugroho Dwijowijoto. 2006. Manajemen Pembangunan Indonesia. Jakarta: PT. Elex Media Komputindo. 